\title{
Fish oil consumption prevents glucose intolerance and hypercorticosteronemy in footshock-stressed rats
}

Ricardo Eguchi', Flavia R Scarmagnani ${ }^{1}$, Claudio A Cunha', Gabriel IH Souza', Luciana P Pisani', Eliane B Ribeiro', Claudia M Oller do Nascimento', Regina C Spadari-Bratfisch² and Lila M Oyama ${ }^{1 *}$

\begin{abstract}
Background: Environmental stress plays an important role in the development of glucose intolerance influencing lipid and glucose metabolism through sympathetic nervous system, cytokines and hormones such as glucocorticoids, catecholamines and glucagon. Otherwise, fish oil prevents glucose intolerance and insulin resistance. Although the mechanisms involved are not fully understood, it is known that sympathetic and HPA responses are blunted and catecholamines and glucocorticoids concentrations can be modulated by fish consumption. The aim of the present study was to evaluate whether fish oil, on a normal lipidic diet: 1) could prevent the effect of footshock-stress on the development of glucose intolerance; 2) modified adiponectin receptor and serum concentration; and 3) also modified TNF- $\alpha$, IL-6 and interleukin-10 (IL-10) levels in adipose tissue and liver. The study was performed in thirty day-old male Wistar randomly assigned into four groups: no stressed (C) and stressed (CS) rats fed with control diet, and no stressed (F) and stressed (FS) rats fed with a fish oil rich diet. The stress was performed as a three daily footshock stress sessions.

Results: Body weight, carcass fat and protein content were not different among groups. FS presented a reduction on the relative weight of RET. Basal serum glucose levels were higher in CS and FS but 15 min after glucose load just CS remained with higher levels than other groups. Serum corticosterone concentration was increased in CS, this effect was inhibited in FS. However, 15 min after footshock-stress, corticosterone levels were similar among groups. IL-6 was increased in EPI of CS but fish oil consumption prevented IL-6 increase in FS. Similar levels of TNF- $\alpha$ and IL-10 in RET, EPI, and liver were observed among groups. Adipo R1 protein concentration was not different among groups. Footshock-stress did not modify AdipoR2 concentration, but fish oil diet increases AdipoR2 protein concentration.
\end{abstract}

Conclusions: Footshock-stress promotes glucose intolerance associated to corticosterone serum level and epididymal white adipose tissue IL-6 concentration increase. The fish oil consumption by stressed rats normalized the stress responses. These results suggested that fish oil intake could be useful to minimize or prevent the development of diseases associated to the stress.

\footnotetext{
* Correspondence: Imoyama@unifesp.br

'Departamento de Fisiologia. Universidade de São Paulo - UNIFESP - Rua Botucatu, 862, 2nd floor, Edifício de Ciências Biomédicas. Vila Clementino, São Paulo, SP, Brazil

Full list of author information is available at the end of the article
} 


\section{Background}

Among environmental factors, stress plays an important role in the induction of glucose intolerance. There are two major components of the stress response: the autonomic nervous system and the hypothalamic-pituitaryadrenal axis (HPA) [1].

The regulation of glucose and lipid metabolism is under the influence of the sympathetic nervous system, cytokines [2], and increased plasmatic levels of glucocorticoids and glucagon acting synergistically with the catecholamines to increase glycemia during stress [3]. Corticosterone, in rodents, is a hormone released by adrenal cortex after the activation of HPA axis [1] and increases glucose production by the liver and decreased peripheral glucose transport and utilization [4].

Glucocorticoids cause a decrease in adipocyte gene expression and secretion of adiponectin and interleukin6 (IL- 6) [5,6]. On the other hand, in primary cultures of murine adipocytes, norepinephrine, isoprenaline, and a $\beta 3$-selective agonist have been shown to stimulate IL6 gene expression and protein secretion [6].

Moreover, pro-inflammatory adipokines, such as tumor necrosis factor- $\alpha$ (TNF- $\alpha$ ) and IL-6 lead to the development of insulin resistance $[7,8]$. Conversely, adiponectin (anti-inflammatory adipokine), binding to its receptors expressed in fat, liver and muscle tissues, activates several intracellular signaling pathways and improves insulin sensitivity, promoting glucose utilization, increasing fatty acid oxidation and, glucose uptake in the muscle, and reducing gluconeogenesis in the liver [9].

Previously, we have shown that three daily sessions of foot-shock stress in rat caused an increase in the plasma corticosterone, insulin and glucose levels accompanied by insulin resistance in isolated white adipocytes and soleus muscle. These results demonstrated that footshock stress could be a useful model for studying glucose intolerance and insulin resistance $[10,11]$.

Several studies have been shown that fish oil could prevent glucose intolerance and insulin resistance $[12,13]$. It has been demonstrated in both human [14-16] and animals models [17-19] the beneficial antistress effects of fish oil on stress response. The mechanisms by which fish oil consumption exerts the anti-stress effect are not fully understood. But it is known that sympathetic and HPA response are blunted [14] and fish oil can modulate catecholamines and glucocorticoids concentrations $[15,16]$.

The majority of the research, about the effects of fish oil on glucose tolerance and insulin resistance, utilized a high fat diet or additional supplementation. In these sense, the aim of the present study was to evaluate whether fish oil, on a normal lipidic diet: 1) could prevent the effect of footshock-stress on the development of glucose intolerance; 2) modified adiponectin receptor and serum concentration; and 3) also modified TNF- $\alpha$, IL-6 and interleukin-10 (IL-10) levels in adipose tissue and liver. These results could contribute to identify whether a normal lipidic diet rich in $n-3$ polyunsaturated fatty acid ameliorate the effects of stress on adipokines and on glucose intolerance.

\section{Materials and methods}

\section{Animal care}

All procedures for the care of the animals used in this study were previously approved by the Experimental Research Committee of the Federal University of São Paulo (protocol n ${ }^{\circ} 2007 / 1346$ ). Twenty-four male Wistar rats (Rattus norvegicus) were housed collectively (4 rats/ cage) after weaning until $93 \mathrm{~d}$ of life in a light (12 h light/dark cycle) and temperature $\left(24 \pm 1^{\circ} \mathrm{C}\right)$ controlled room. Diet and water were available ad libitum. Body weight and food intake were recorded weekly.

Animals were randomly divided into 4 experimental groups: Soybean Non stressed (C), received a diet containing soybean oil as a source of lipids; Fish Oil Non stressed (F), received a diet containing fish oil as a source of lipids; Soybean Stressed (CS), received a diet containing soybean oil as fat source and were submitted, in the 91st to 93rd days of life, to the footshock-stress; and Fish Oil Stressed (FS), received a diet containing fish oil as fat source and were submitted to the footshock-stress sessions.

\section{Diet composition}

After weaning until $60 \mathrm{~d}$ of life the rats were feed with growth diet (AIN-93G), containing 20\% protein and $8 \%$ lipids, as described by American Institute of Nutrition (AIN-93) [20]. After $60 \mathrm{~d}$ of life, until $93 \mathrm{~d}$ of life rats were fed with a maintenance diet (AIN -93M), with 5\% lipids and $14 \%$ protein. $\mathrm{C}$ and CS diet contained soybean oil (Liza ${ }^{\circledR}$, Itumbiara-GO, Brazil) as lipid source. While F and FS diet contained fish oil as lipid source (Campestre ${ }^{\circledR}$, São Bernardo do Campo-SP, Brazil).

\section{Stress Procedure}

Each rat underwent three daily sessions of unsignaled, inescapable footshocks. The animals were placed in a Plexiglas chamber $(26 \times 21 \times 26 \mathrm{~cm})$ provided with a grid floor made of stainless-steel rods $(0.3 \mathrm{~cm}$ in diameter and spaced $1.0 \mathrm{~cm}$ apart). During the $30 \mathrm{~min}$ sessions, which occurred between 8:00 and 10:30 am, the footshocks were delivered by a constant current source controlled by a microprocessor, with constant intensity of $1.0 \mathrm{~mA}$, with a duration of $1 \mathrm{~s}$ at random intervals of 5-25 s (mean interval of $15 \mathrm{~s}$ ) [11]. In the first and second sessions of stress the rats were at the fed state. At 
the third session of stress, rats were fasted for $12 \mathrm{~h}$ to perform the Oral Glucose Tolerance Test (OGTT) after the last session of stress.

\section{Oral glucose tolerance test (OGTT)}

After $12 \mathrm{~h}$ fasting, body weight recording and the third footshock-stress session for the stressed rats (CS and FS), all groups were submitted to OGTT. The test started with collection of blood samples through a small incision in tail to determine baseline parameters. Glucose solution (50\% glucose dissolved in saline $0.9 \%$ ) was administered by intragastric gavage $(2 \mathrm{~mL} / \mathrm{kg})$. Blood samples were collected at 15, 30, 45, 60 and 90 minutes after glucose load. Throughout the procedure animals were awake and free moving in the cage. To calculate area under the curve (AUC) we used Matthews et al. [21] formula's: $\mathrm{AUC}=1 / 2 \sum_{i=0}^{n-1}\left(\mathrm{t}_{\mathrm{i}+1}-\mathrm{t}_{\mathrm{i}}\right)\left(\mathrm{y}_{\mathrm{i}}+y_{\mathrm{i}+1}\right)$; where " $t$ " means time and " $y$ " concentration.

\section{Biochemical and Hormonal serum analysis}

Blood samples collected after the last stress session and before the glucose load administered in the OGTT was used to evaluate the baseline blood glucose, adiponectin and insulin concentration. Serum Insulin (R\&D Systems $^{\circledR}$, Minneapolis-MN, USA), adiponectin (R\&D Systems ${ }^{\circledR}$, Minneapolis-MN, USA) and corticosterone (Stressgen ${ }^{\circledR}$, Ann Harbor-MI, USA) concentrations and TNF- $\alpha$, IL-6 and IL-10 (R\&D Systems ${ }^{\circledR}$, MinneapolisMN, USA) in adipose tissue and liver levels were determined by enzyme-linked immunosorbent assay (ELISA). Glucose was determined with the commercially available kit PAP Liquiform Glucose (Labtest ${ }^{\circledR}$, Lagoa Santa-MG, Brazil). Protein was quantified with the BCA Reagent for proteins - Lowry Modified (BioAgency ${ }^{\circledR}$, São PauloSP, Brazil).

\section{Carcass lipid and protein content}

Carcasses were eviscerated, weighed, and stored at $-20^{\circ}$ C. Lipid content was measured as described by Stansbie et al. [22] and standardized using the method described by do Nascimento and Williamson [23]. Briefly, the eviscerated carcass was autoclaved at $120^{\circ} \mathrm{C}$ for $90 \mathrm{~min}$ and homogenized with double the mass of water. Triplicate aliquots of this homogenate were weighed and digested in $3 \mathrm{ml}$ of $30 \% \mathrm{KOH}$ and $3 \mathrm{ml}$ of ethanol for at least 2 $\mathrm{h}$ at $70^{\circ} \mathrm{C}$ in capped tubes. After cooling, $2 \mathrm{ml}$ of $12 \mathrm{~N}$ $\mathrm{H}_{2} \mathrm{SO}_{4}$ were added and the sample was washed three times with petroleum ether for lipid extraction. Results are expressed as grams of lipid per $100 \mathrm{~g}$ of carcass. For protein measurements, aliquots of the same homogenate were heated to $37^{\circ} \mathrm{C}$ for 1 hour in $0.6 \mathrm{~N} \mathrm{KOH}$ with constant shaking. After clarification by centrifugation, protein content was quantified.

\section{Western blotting procedures}

Animals were decapitated. Retroperitoneal (RET) and epididymal (EPI) adipose tissues and liver were removed and homogenized in ice-cold solubilization and total protein extraction buffer (100 mM Tris, pH 7.5, $10 \mathrm{mM}$ ethylene acetic acid, $100 \mathrm{mM}$ sodium fluoride, $10 \mathrm{mM}$ sodium orthovanadate, $2 \mathrm{mM}$ phenylmethylsulfonyl fluoride, $10 \mathrm{mM}$ sodium pyrophosphate and $0.1 \mathrm{mg} / \mathrm{mL}$ aprotinin. After homogenization, Triton X-100 was added, to a final concentration of $1 \%$. Samples rested in ice for $30 \mathrm{~min}$ and were clarified by centrifugation. Equal amounts of protein $(30 \mu \mathrm{g}$ for liver and $120 \mu \mathrm{g}$ for RET and EPI) were loaded in $10 \%$ sodium dodecylsulfate polyacrylamide gel electrophoresis, electrophoretically separated, and transferred to nitrocellulose membranes. Membranes were incubated with the appropriate primary antibody: AdipoR1 (SC-46748), AdipoR2 (SC-46751), HSD1 (SC-20175) and $\alpha$-tubulin (SC58664) (Santa Cruz Biotechnology ${ }^{\circledR}$, Santa Cruz-CA, USA). After secondary antibody incubation, detection was performed by chemiluminescence with an enhanced chemiluminescence reagent (Amersham Biosciences ${ }^{\circledR}$, Piscataway-NJ, USA). Membranes were stripped and reblotted with $\alpha$-tubulin. Quantitative analyses were performed with Image ${ }^{\circledR}$ software and the results as standardized with $\alpha$-tubulin as load control. Data are expressed as percentage (\%) of control.

\section{Data analysis}

The results are expressed as mean \pm SEM. For multiple comparisons of means was performed analysis of variance (ANOVA) two-way with subsequent use of the Tukey post-hoc test. Statistical significance was set at $P<0.05$.

\section{Results}

\section{General characteristics of the experimental groups}

Body weight, carcass fat and protein content (Table 1) and food intake (data not showed) were similar among all groups.

Neither footshock-stress nor fish oil consumption altered relative weight of RET, EPI and liver. However, the association of fish oil consumption and footshockstress reduced the relative weight of RET in relation to $\mathrm{C}$, with no differences in EPI and liver (Table 1).

\section{OGTT and Biochemical and Hormonal serum analysis}

Basal serum glucose levels were higher in stressed (CS and FS) than in non stressed ( $\mathrm{C}$ and F) animals. However, 15 min after glucose load, CS serum glucose levels remained elevated compared to other groups, but fish oil ingestion abolished the effect of footshock-stress on glucose levels (Figure 1A). Conversely, glucose AUC was similar among groups (Figure 1B). 
Table 1 Animal characteristics from body composition, serum basal levels of adiponectin, insulin, glucose and corticosterone of Control (C), Stressed (CS), Fish Oil (F) and Fish oil Stressed (FS) groups

\begin{tabular}{|c|c|c|c|c|c|}
\hline & $\mathrm{C}$ & CS & $\mathrm{F}$ & FS & $p$ \\
\hline Initial body weight (g) & $94.6 \pm 3.4$ & $94.6 \pm 5.1$ & $91.9 \pm 3.9$ & $92.2 \pm 3.2$ & ns \\
\hline Final body weight (g) & $369.2 \pm 9.3$ & $373.3 \pm 10.9$ & $376.9 \pm 9.5$ & $361.6 \pm 10.2$ & ns \\
\hline \multicolumn{6}{|l|}{ Carcass content } \\
\hline Protein $(\mathrm{g} / 100 \mathrm{~g})$ & $16.3 \pm 1.6$ & $16.9 \pm 0.9$ & $17.1 \pm 1.8$ & $18.9 \pm 1.5$ & ns \\
\hline Fat $(g / 100 \mathrm{~g})$ & $8.6 \pm 1.0$ & $8.8 \pm 1.2$ & $7.7 \pm 1.2$ & $8.0 \pm 1.1$ & ns \\
\hline \multicolumn{6}{|l|}{ Relative weight } \\
\hline RET $(g / 100 \mathrm{~g})$ & $2.00 \pm 0.17$ & $1.54 \pm 0.15$ & $1.48 \pm 0.09$ & $1.24 \pm 0.17^{*}$ & 0.05 \\
\hline EPI (g/100 g) & $2.12 \pm 0.20$ & $1.97 \pm 0.18$ & $1.71 \pm 0.26$ & $1.43 \pm 0.11$ & ns \\
\hline LIV (g/100 g) & $2.88 \pm 0.05$ & $2.83 \pm 0.13$ & $2.91 \pm 0.08$ & $2.65 \pm 0.03$ & ns \\
\hline Adiponectin $(\mathrm{mg} / \mathrm{mL})$ & $7.34 \pm 0.56$ & $8.04 \pm 0.71$ & $7.57 \pm 0.54$ & $7.49 \pm 0.58$ & ns \\
\hline Insulin (ng/mL) & $1.01 \pm 0.37$ & $0.96 \pm 0.29$ & $0.75 \pm 0.16$ & $0.67 \pm 0.21$ & ns \\
\hline Glucose (mg/dL) & $95.1 \pm 3.4$ & $133.4 \pm 10.1 \S$ & $93.5 \pm 3.0$ & $125.19 \pm 6.0 \S$ & 0.0001 \\
\hline Corticosterone (ng/mL) & $182.0 \pm 23.5$ & $376.1 \pm 40.1^{*}$ & $122.2 \pm 9.1$ & $108.8 \pm 42.7$ & 0.04 \\
\hline
\end{tabular}

Data are means \pm SEM. $N=6$ rats/group. ${ }^{*}$ Different from Control (C) group $p<0.05$. Different from Control (C) and Fish Oil (F) groups $p<0.05$.

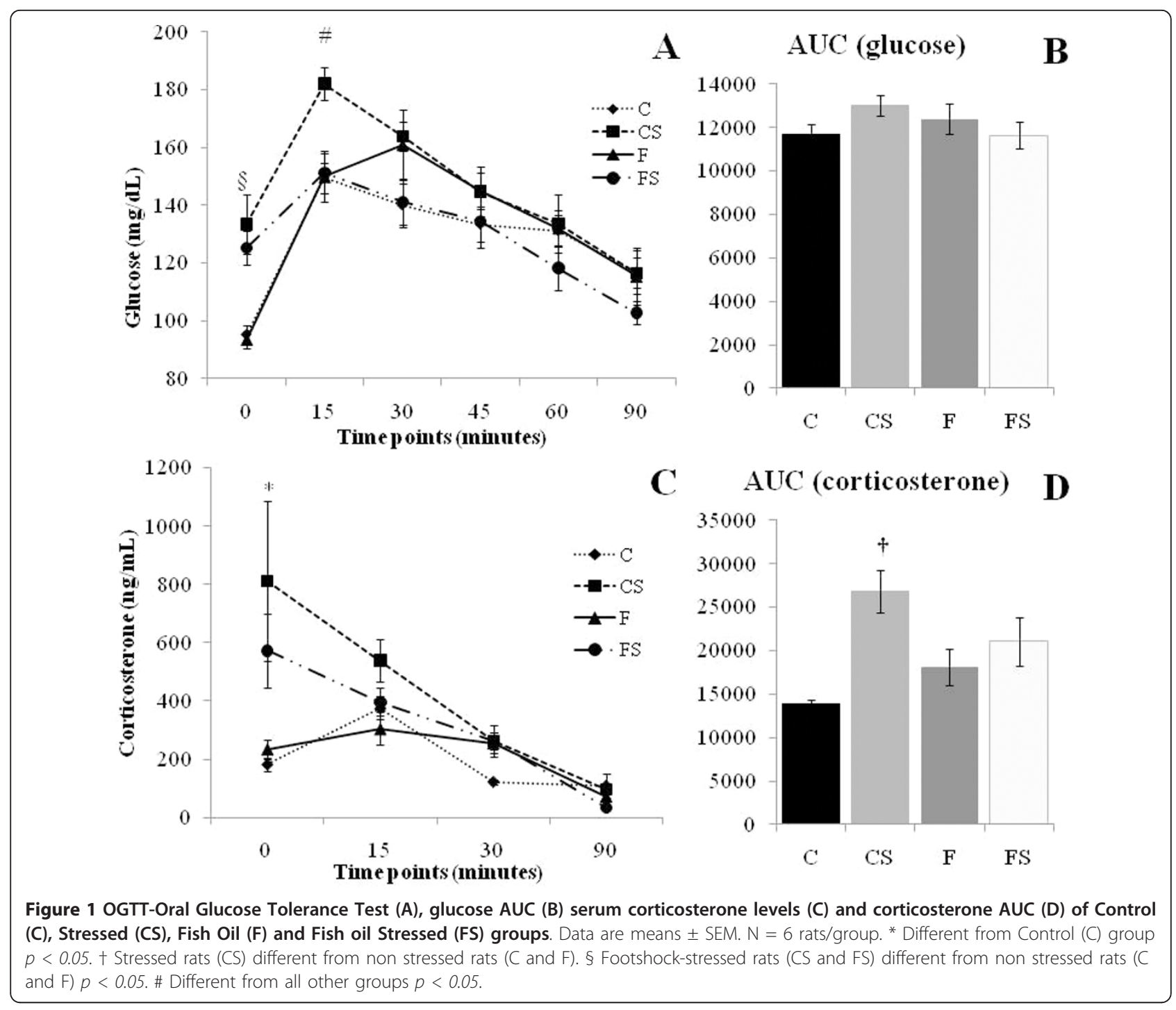


Insulin and adiponectin serum concentration were similar among groups (Table 1).

Immediately after footshock-stress, serum corticosterone concentration was increased in CS, but fish oil diet inhibits this effect (FS) (Table 1). 15 min after footshockstress session, corticosterone levels were similar among groups (Figure 1C). Still, CS corticosterone AUC was higher than the others groups (C, F and FS) (Figure 1D).

\section{IL-6, TNF- $\alpha$. and IL-10 levels in RET, EPI and liver}

Footshock-stress (CS) lead to an increase of IL-6 levels in EPI compared to C. Fish oil consumption (F) did not alter IL-6 levels and prevented IL-6 increase in footshock-stressed animals (FS) (figure 2C). Similar levels of TNF- $\alpha$ and IL-10 in RET, EPI, and liver were observed among groups (figure $2 \mathrm{~A}, \mathrm{~B}$ ).

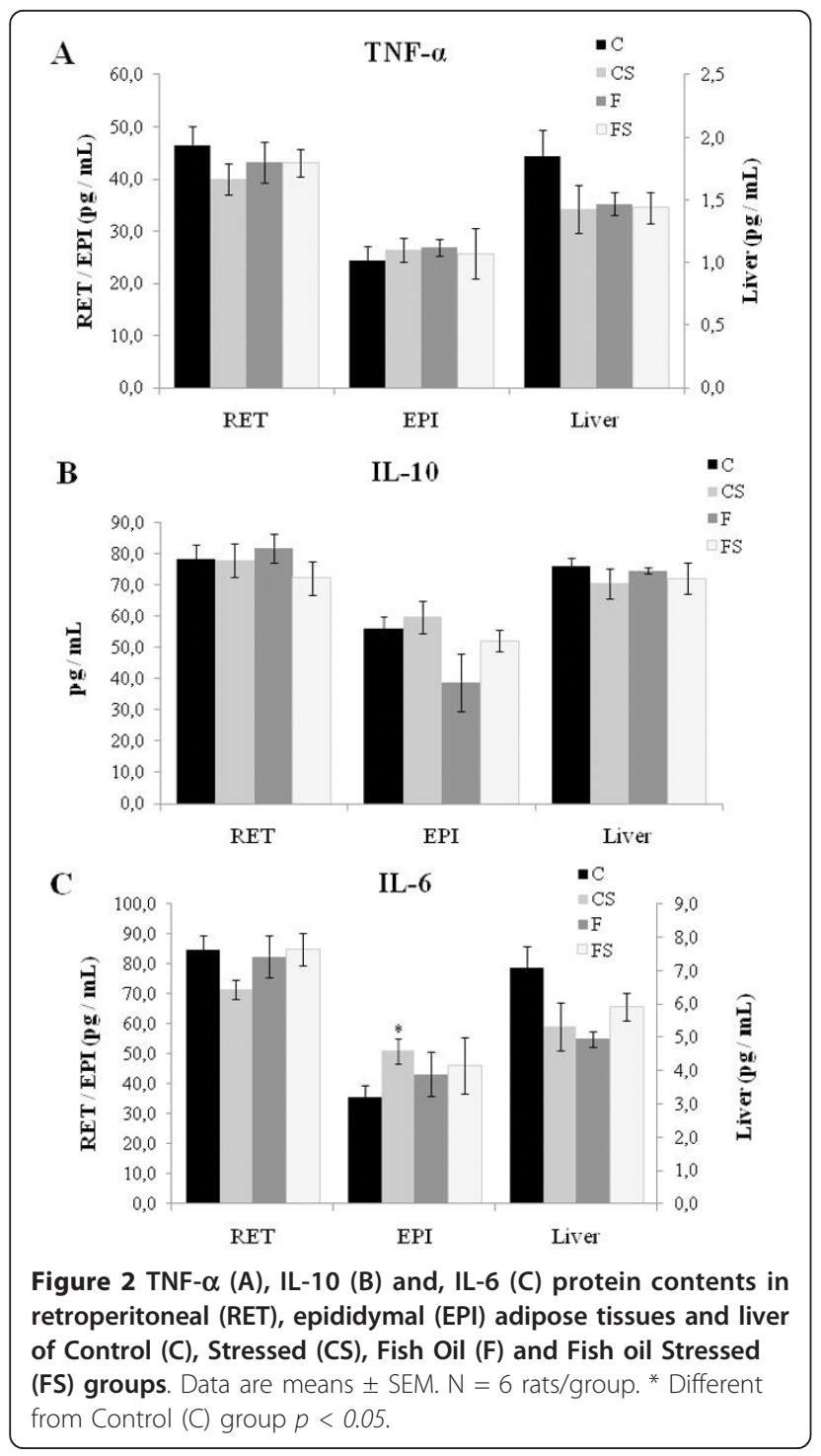

AdipoR1/R2 quantity in adipose tissue and liver

Adipo R1 protein concentration was similar in the study tissues among groups (Figure 3A). The footshock-stress did not modify AdipoR2 concentration in studied groups. Although, fish oil diet increases AdipoR2 protein concentration in RET as compared to control diet (F vs. C) (Figure 3B).

\section{Discussion}

The present study shows that footshock-stress caused a glucose intolerance accompanied by an increase in corticosterone level and IL- 6 epididymal protein content. The fish oil consumption blunted these effects of stress, demonstrating the preventive effect of fish oil consumption in development of glucose intolerance promoted by footshock-stress.

The final body weight and carcasses lipid and protein content were not modified by 3 days of footshock-stress and/or fish oil consumption for 8 weeks. Previously, Papakonstantinou et al. [24], using a repeated restraint stress for 3 days, 3 hours per day, showed that consumption of hyperlipidic diet rich with fish oil (2 weeks

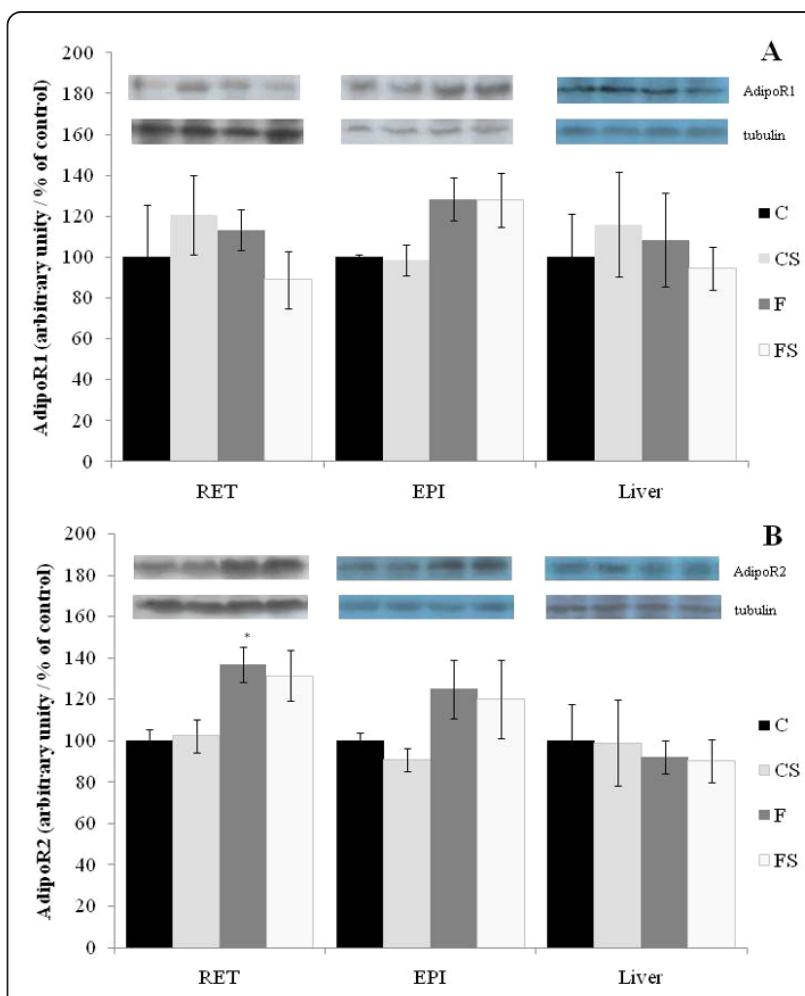

Figure 3 AdipoR1(A) and AdipoR2 (B) protein contents in retroperitoneal (RET), epididymal (EPI) adipose tissues and liver of Control (C), Stressed (CS), Fish Oil (F) and Fish oil Stressed (FS) groups. Results were quantified by densitometry and $\alpha$-tubulin was used as load control. Data are expressed as \% of control (C) and are means \pm SEM. $N=6$ rats/group. ${ }^{*}$ Different from Control (C) group $p<0.05$. 
before stress and 2 after) did not ameliorate stressinduced anorexia and weight loss. Similar results was observed in rats treated with normolipidic diet containing fish oil for 45 days submitted for 96 hours of sleep deprivation [25]. Taken these results all together it could be suggested that the duration of fish oil ingestion and type of stressor could influence the effect of stress in body weight.

However, in the present study the footshock-stress in fish oil treated rats caused a decrease in RET weight. Fish oil reduces fatty acid accumulation $[26,27]$ and prevents diet induced obesity [28], mainly through the regulation of lipid metabolism by inhibiting lipogenesis, promoting lipolysis and fatty acid oxidation, and suppressing preadipocyte differentiation [29].

As previously reported $[10,11]$ footshock-stress caused a glucose intolerance and increase corticosterone serum levels, in addition in the present study we demonstrated that the ingestion for 8 weeks of normolipidic diet rich in fish oil prevented these effects.

Insulin resistance promoted by glucocorticoid has long been known and is associated with increased hepatic glucose production and decreased peripheral glucose transport and utilization [4]. In the present study, CS exhibited a marked increase in corticosterone concentrations in relation to all other groups, including FS, which reflects OGTT response. This result suggests that glucose intolerance promoted by footshock occurred in response to activation of HPA axis, and that consumption of fish oil blunted this effect, protecting against glucose intolerance. This result underscores the anti-stress effect of fish oil consumption.

Based on these find, we seek to establish whether the effect of fish oil was not only related to the normal corticosterone level observed in FS group, but also if it could be associated to fish oil effects on adipokines related to glucose intolerance.

The increase in adipoR2 in fish oil fed rats might be involved in this response, but further investigations will be required to elucidate the mechanisms involved.

The insulin-sensitizing adipokine adiponectin is another important factor involved in glucose intolerance $[30,31]$. Adiponectin is specifically expressed in adipose tissue and has antiatherogenic and antidiabetic properties [31-33] and its effects are mediated by adiponectin receptors, adipoR1 and adipoR2 [32]. AdipoR1 is abundantly expressed in skeletal muscle, whereas adipoR2 is predominantly found in liver $[31,32]$ and both are also expressed in adipose tissue [32].

The effects of stress and glucocorticoids on adiponectin regulation are controversial. In human adipocytes, dexamethasone inhibits adiponectin release [34]. In human volunteers treated with dexamethasone plasma adiponectin levels were unchanged [35], while in another study a small rise was found [36] but adiponectin was decreased in subjects treated with hydrocortisone [37]. Catecholamine also modulates adiponectin, $\beta$-adrenergic stimulation downregulate adiponectin gene expression $[30,38]$ but upregulates AdipoR2 expression [30]. These data suggest that fish oil consumption, although not alter serum levels of adiponectin, may have improved the sensitivity to this hormone contributing to the protective effect of fish oil on glucose intolerance induced by stress.

Increase in pro-inflammatory adipokines, such as TNF- $\alpha$ and IL-6, also leads to glucose intolerance and insulin resistance [7].

The fish oil and stress have been reported to exert pro and anti-inflammatory effects $[29,39]$. In these sense, we decided to measured the retroperitoneal and epididymal white adipose tissue and liver TNF- $\alpha$, IL- 6 and IL-10 protein content.

Neither footshock-stress, fish oil consumption nor the interaction between fish oil and footshock-stress caused modification on TNF- $\alpha$ and IL-10 protein content in the studied tissues. However, the footshock-stress increased IL-6 protein concentration in EPI and fish oil consumption impaired this effect.

Glucocorticoids cause a decrease in adipocyte gene expression and secretion of adiponectin and IL- $6[5,6]$. On the other hand, in primary cultures of murine adipocytes, norepinephrine, isoprenaline, and a $\beta 3$-selective agonist have been shown to stimulate IL-6 gene expression and protein secretion [6]. Conversely, fish oil rich diet decreased plasma levels of norepinephrine in healthy subjects [40]. In the present study, the decrease in EPI IL-6 protein content in FS group is not related to an increase in glucocorticoid, since stress did not modified this hormone concentration in fish oil treated rats. However, taken our results with the literature ones, the decrease in IL-6 could be related to a decrease in norepinephrine caused by fish oil diet in stressed rats (FS). The catecholamines were not evaluated, which is a limiting factor in this study, since these hormones, like corticosterone, reflect the stress response and affects many metabolic effects. However the measurement of serum corticosterone demonstrated its important role in the footshock-stress and fish oil consumption response.

Adipose tissue IL-6 production may account for about $25 \%$ of the circulating IL-6 [41]. Then, the decrease in IL-6 in EPI of FS comparing to CS reflect, probably, in the serum IL-6 concentration and in the normal glucose tolerance test observed in FS rats in relation to CS rats.

In summary, footshock-stress promoted glucose intolerance associated to corticosterone serum level and epididymal white adipose tissue IL-6 concentration increase. The fish oil consumption by stressed rats normalized the stress responses. These results suggested 
that fish oil intake could be useful to minimize or prevent the development of diseases associated to the stress.

\section{Acknowledgements}

The authors gratefully acknowledge the invaluable assistance of Mauro Cardoso Pereira for the animal care and Coordenação de Aperfeiçoamento de Pessoal de Nível Superior (CAPES) for the financial support. This work was also supported by grants from Conselho Nacional de Desenvolvimento Científico e Tecnológico (CNPq).

\section{Author details}

'Departamento de Fisiologia. Universidade de São Paulo - UNIFESP - Rua Botucatu, 862, 2nd floor, Edifício de Ciências Biomédicas. Vila Clementino, São Paulo, SP, Brazil. 'Departamento de Biociências. Universidade Federal de São Paulo - UNIFESP - Av. Ana Costa, 95. Vila Mathias, Santos, SP, Brazil.

\section{Authors' contributions}

RE made substantial contributions to conception and design, all the experimental analysis and acquisition of data and also analysis and interpretation of data. FRS carried out the experimental analysis and acquisition of data. CAC carried out the experimental analysis and acquisition of data. GIHS carried out the experimental analysis and acquisition of data. LPP participated in all molecular and biochemical analyzes. EBR participated in the design of the study and helped to draft the manuscript. CMON participated in the design of the study and performed the statistical analysis and helped to draft the manuscript. RCSB participated in the design of the study and helped to draft the manuscript. LMO has made substantial contributions to conception and design, analysis and interpretation of data and coordination to draft the manuscript. All authors read and approved the final manuscript.

\section{Competing interests}

The authors declare that they have no competing interests.

Received: 23 March 2011 Accepted: 11 May 2011

Published: 11 May 2011

\section{References}

1. Bose $M$, Oliván B, Laferrère B: Stress and obesity: the role of the hypothalamic-pituitary-adrenal axis in metabolic disease. Curr Opin Endocrinol Diabetes Obes 2009, 16:340-346.

2. Nonogaki K: New insights into sympathetic regulation of glucose and fat metabolism. Diabetologia 2000, 43:533-549.

3. Yamada F, Inoue S, Saitoh T, Tanaka K, Satoh S, Takamura Y: Glucoregulatory hormones in the immobilization stress-induced increase of plasma glucose in fasted and fed rats. Endocrinology 1993, 132:2199-2205.

4. Saad MJA, Folli F, Kahn JA, Kahn CR: Modulation of insulin receptor, insulin receptor substrate-1, and phosphatidylinositol 3-kinase in liver and muscle of dexamethasone-treated rats. J Clin Invest 1993, 92:2065-2072.

5. Shi JH, Du WH, Liu XY, Fan YP, Hu XL, Zhou HY, Xu HB, Zhang XM, Xiang P, Chen FL: Glucocorticoids decrease serum adiponectin level and WAT adiponectin mRNA expression in rats. Steroids 2010, 75:853-858.

6. Mohamed-Ali V, Pinkney JH, Coppack SW: Adipose tissue as an endocrine and paracrine organ. Int J Obes 1998, 22:1145-1158.

7. Tilg $H$, Moschen AR: Inflammatory mechanisms in the regulation of insulin resistance. Mol Med 2008, 14:222-231.

8. Bastard JP, Jardel C, Bruckert E, Blondy P, Capeau J, Laville M, Vidal H, Hainque B: Elevated levels of interleukin- 6 are reduced in serum and subcutaneous adipose tissue of obese women after weight loss. J Clin Endocrinol Metab 2000, 85:3338-3342.

9. Ziemke F, Mantzoros CS: Adiponectin in insulin resistance: lessons from translational research. Am J Clin Nutr 2010, 91(suppl):258S-261S.

10. Verago JL, Grassi-Kassisse DM, Spadari-Bratfisch RC: Metabolic markers following beta-adrenoceptor agonist infusion in footshock-stressed rats. Braz J Med Biol Res 2001, 34:1197-1207.
11. Farias-Silva E, Sampaio-Barros MM, Amaral MEC, Carneiro EM, Boschero AC, Grassi-Kassisse DM, Spadari-Bratfisch RC: Subsensitivity to insulin in adipocytes from rats submitted to foot-shock stress. Can J Physiol Pharmacol 2002, 80:783-789.

12. Rossmeisl M, Jelenik T, Jilkova Z, Slamova K, Kus V, Hensler M, Medrikova D, Povysil C, Flachs P, Mohamed-Ali V, Bryhn M, Berge K, Holmeide AK, Kopecky J: Prevention and Reversal of Obesity and Glucose Intolerance in Mice by DHA Derivatives. Obesity 2009, 17:1023-1031.

13. Samane S, Christon R, Dombrowski L, Turcotte S, Charrouf Z, Lavigne C, Levy E, Bachelard H, Amarouch H, Marette A, Haddad PS: Fish oil and argan oil intake differently modulate insulin resistance and glucose intolerance in a rat model of dietary-induced obesity. Metabolism 2009, 58:909-919.

14. Michaeli B, Berger MM, Revelly JP, Tappy L, Chioléro R: Effects of fish oil on the neuro-endocrine responses to an endotoxin challenge in healthy volunteers. Clin Nutr 2007, 26:70-77.

15. Hamazaki T, Itomura M, Sawazaki S, Nagao Y: Anti-stress effects of DHA. Biofactors 2000, 13:41-45

16. Delarue J, Li CH, Cohen R, Corporeau C, Simon B: Interaction of fish oil and a glucocorticoid on metabolic responses to an oral glucose load in healthy human subjects. Br J Nutr 2006, 95:267-272.

17. Corporeau C, Foll C, Taouis M, Gouygou JP, Berge JP, Delarue J: Adipose tissue compensates for defect of phosphatidylinositol 3'-kinase induced in liver and muscle by dietary fish oil in fed rats. Am J Physiol Endocrinol Metab 2006, 290:78-86.

18. Song C, Li X, Leonard BE, Horrobin DF: Effects of dietary $n-3$ or $n-6$ fatty acids on interleukin- $1 \beta$-induced anxiety, stress, and inflammatory responses in rats. J Lipid Res 2003, 44:1984-1991.

19. Takeuchi T, Iwanaga M, Harada E: Possible regulatory mechanism of DHA-induced anti-stress reaction in rats. Brain Res 2003, 964:136-143.

20. Reeves PG: Components of the AIN-93 diets as improvements in the AIN-76A diet. J Nutr 1997, 127:838-841.

21. Matthews JNS, Altman DG, Campbell MJ, Royston P: Analysis of serial measurements in medical research. Br Med J 1990, 300:230-235.

22. Stansbie D, Denton RM, Bridges BJ, Pask HT, Randle PJ: Regulation of pyruvate dehydrogenase and pyruvate dehydrogenase phosphate phosphatase activity in rat epididymal fat-pads. Effects of starvation, alloxan-diabetes and high-fat diet. Biochem J 1976, 154:225-236.

23. do Nascimento CM, Williamson DH: Evidence for conservation of dietary lipid in the rat during lactation and the immediate period after removal of the litter. Biochem J 1986, 239:233-236

24. Papakonstantinou E, Ryan DH, Harris RBS: Dietary fish oil does not protect rats exposed to restraint or sleep deprivation stress. Physiol Behav 2003, 78:759-765.

25. de Mattos AB, Pinto MJ, Oliveira C, Biz C, Ribeiro EB, do Nascimento $C M$, Andersen ML, Tufik S, Oyama LM: Dietary fish oil did not prevent sleep deprived rats from a reduction in adipose tissue adiponectin gene expression. Lipids Health Dis 2008, 7:43.

26. Pighin D, Karabatas L, Rossi A, Chicco A, Basabe JC, Lombardo YB: Fish Oil affects pancreatic fat storage, pyruvate dehydrogenase complex activity and insulin secretion in rats fed a sucrose-rich diet. J Nutr 2003, 133:4095-4101.

27. Carpentier YA, Portois L, Malaisse WJ: $n-3$ fatty acids and the metabolic syndrome. Am J Clin Nutr 2006, 83(Suppl 6):1499-1504.

28. Huang XF, Xin X, McLennan P, Storlien L: Role of fat amount and type in ameliorating diet-induced obesity: insights at the level of hypothalamic arcuate nucleus leptin receptor, neuropeptide $Y$ and proopiomelanocortin mRNA expression. Diabetes Obes Metab 2004, 6:35-44.

29. Tai CC, Ding ST: N-3 polyunsaturated fatty acids regulate lipid metabolism through several inflammation mediators: mechanisms and implications for obesity prevention. J Nutr Biochem 2010, 21:357-363.

30. Kadowaki T, Yamauchi T, Kubota N, Hara K, Ueki K, Tobe K: Adiponectin and adiponectin receptors in insulin resistance, diabetes, and the metabolic syndrome. J Clin Invest 2006, 116:1784-1792.

31. Fu L, Isobe K, Zeng Q, Suzukawa K, Takekoshi K, Kawakami Y: $\beta$ adrenoceptor agonists downregulate adiponectin, but upregulate adiponectin receptor 2 and tumor necrosis factor-a expression in adipocytes. Eur J Pharmacol 2007, 569:155-162.

32. Blüher M, Fasshauer M, Kralisch S, Schön MR, Krohn K, Paschke R: Regulation of adiponectin receptor R1 and R2 gene expression in 
adipocytes of C57BL/6 mice. Biochem Biophys Res Commun 2005, 329:1127-1132.

33. Neschen S, Morino K, Rossbacher JC, Pongratz RL, Cline GW, Sono S, Gillum M, Shulman Gl: Fish oil regulates adiponectina secretion by a peroxisome proliferator-actived receptor- $\gamma$-dependent mechanism in mice. Diabetes 2006, 55:924-928.

34. Degawa-Yamauchi M, Moss KA, Bovenkerk JE, Shankar SS, Morrnson CL, Lelliot CJ, Vidal-Puig A, Jones R, Considine RV: Regulation of adiponectin expression in human adipocytes: Effects of adiposity, glucocorticoids, and tumor necrosis factor-a. Obes Res 2005, 13:662-669.

35. Patel JV, Cummings DE, Girod JP, Mascarenhas AV, Hughes EA, Gupta M, Lip GY, Reddy S, Brotman DJ: Role of metabolically active hormones in the insulin resistance associated with short-term glucocorticoid treatment. J Negat Results Biomed 2006, 5:14.

36. Jang C, Inder WJ, Obeyesekere VR, Alford FP: Adiponectin, skeletal muscle adiponectina receptor expression and insulin resistance following dexamethasone. Clin Endocrinol 2008, 69:745-750.

37. Fallo F, Scarda A, Sonino N, Paolleta A, Boscaro M, Pagano C, Federspil G, Vettor R: Effect of glucocorticoids on adiponectin: a study in healthy subjects and in Cushing's Syndrome. Eur J Endocrinol 2004, 150:339-344.

38. Fasshauer M, Klein J, Neumann S, Eszlinger M, Paschke R: Adiponectin gene expression is inhibited by beta-adrenergic stimulation via protein kinase A in 3T3-L1 adipocytes. FEBS Lett 2001, 507:142-146.

39. Liu YL, Bi H, Chi SM, Fan R, Wang YM, Ma XL, Chen YM, Luo WJ, Pei JM, Chen JY: The effect of compound nutrients on stress-induced changes in serum IL-2, IL-6 and TNF-alpha levels in rats. Cytokine 2007, 37:14-21.

40. Hamazaki K, Itomura M, Huan M, Nishizawa H, Sawazaki S, Tanouchi M, Watanabe S, Hamazaki T, Terasawa K, Yazawa K: Effect of omega-3 fatty acid-containing phospholipids on blood catecholamine concentrations in healthy volunteers: a randomized, placebo-controlled, double-blind trial. Nutrition 2005, 21:705-710.

41. Mohamed-Ali V, Goodrick S, Rawesh A, Katz DR, Miles JM, Yudkin JS, Klein S, Coppack SW: Subcutaneous adipose tissue releases interleukin-6, but not tumor necrosis factor-alpha, in vivo. J Clin Endocrinol Metab 1997, 82:4196-4200.

doi:10.1186/1476-511X-10-71

Cite this article as: Eguchi et al:: Fish oil consumption prevents glucose intolerance and hypercorticosteronemy in footshock-stressed rats. Lipids in Health and Disease 2011 10:71.

\section{Submit your next manuscript to BioMed Central and take full advantage of:}

- Convenient online submission

- Thorough peer review

- No space constraints or color figure charges

- Immediate publication on acceptance

- Inclusion in PubMed, CAS, Scopus and Google Scholar

- Research which is freely available for redistribution

Submit your manuscript at www.biomedcentral.com/submit
Biomed Central 